\title{
Mali: \\ ECOWAS Responses to the Conflict in MALI \\ (2012-2021)
}

\author{
Enoch Ndem OKON
}

\begin{abstract}
This paper highlights the Economic Community of West African States [ECOWAS] mode of response to the Malian conflict between 2012 and 2021 and identifies various gaps therein. It seeks to explain why ECOWAS has found it difficult to resolve the Malian conflict in spite of its commitment and experience in conflict resolution in the subregion. Secondary data are used for the study and presented qualitatively. The study reveals that the towering interest of Algeria and other neighbors in the chaotic northern Mali, as well as French interest in its former colony hindered ECOWAS initiative and its effectiveness in resolving the conflict. The paper recommends ECOWAS' involvement in negotiations at the next peace agreement, and the drawing up of a roadmap for implementing such agreement. Besides, ECOWAS needs to address governance deficits in Mali and elsewhere in the subregion through peer review mechanism; and increase its capacity to respond to violent conflicts beyond microstates and Anglophone enclaves in the region.
\end{abstract}

Keywords: ECOWAS, Malian conflict, military coup, Tuareg, Jihad.

\section{Introduction}

Between 1960 and 2021, Mali has experienced five military coups and Tuareg rebellions, four transition to civil rule programs and five unimplemented North-South peace agreements, as well as a democratic turnover. These are symptoms of protracted conflict rooted in the foundation of the state, the process of state building and consolidation, and efforts at the institutionalization of liberal democracy in a fragile state. Algeria was the first mediator in the Tuareg rebellion of 1963 which resulted in the Tamanrasset

$$
\begin{aligned}
& \text { Enoch Ndem OKON } \\
& \text { Department of Political Science } \\
& \text { University of Calabar, Nigeria } \\
& \text { E-mail: enochokon@gmail.com }
\end{aligned}
$$

Conflict Studies Quarterly

Issue 37, October 2021, pp. 36-53

DOI: $10.24193 /$ csq.37.3

Published First Online: 05 October /2021 
Peace Agreement. Similarly, the second agreement (Pacte National) was facilitated by Algeria, Mauritania and France, which was signed in April 1992 at Bamako. The Pacte contained provisions for the transformation of the enmity relationship between the South and North to amity partnership, required for a democratic polity and socio-economic development. The discontentment within the North over poor implementation of the Pacte, interethnic and intra-Tuareg rivalry led to another rebellion in May 2006 which was resolved with another Algeria mediated agreement in July, the same year. The fall of Muammar Gaddafi in 2011 and the return of Tuareg soldiers, who fought for Gaddafi, in 2012 triggered another rebellion which almost consumed the Malian state, but for foreign intervention. The consequent Algerian mediated agreement has similar provisions with the previous Pacte and are yet to be implemented because of the raging terrorism in Northern Mali. Similarly, three of the military coups - 1968, 1991, 2012 led to military regimes and transition to civil rule. Specifically, ECOWAS was at the forefront of the push towards the restoration of democratic order after the 2012 coup and worked for its fruition in 2013. In spite of its experience and commitment to peace and security in the West African sub-region, it is rather puzzling that ECOWAS finds it difficult to resolve the Malian historical conflicts. The objective of this discourse is to highlight ECOWAS' responses to the Malian conflict since the military coup of 2012, and the gaps in the responses. The paper is divided into seven sections including the introduction, literature review, theoretical framework, methodology, the analysis of the conflict, ECOWAS responses to the conflict, the gaps identified in ECOWAS responses to the conflicts and the conclusion with some recommendations.

\section{Literature Review}

Mali was part of the former French Empire in West Africa as partitioned by the outcome of the Berlin Conference of 1884-1885. It gained independence from the French in 1960 with Bamako as the capital. The country shares boundaries with Mauritania and Senegal in the West, Guinea in the Southwest, Cote d'Ivoire and Burkina Faso in the South, Niger in the East and Algeria in the North.

It is said to be one of the poorest countries in the world and has a population of about 20 million people: It has a diverse ethnic mix with Mande (Bambara, Malinke, and Soninke) making 50\%, Fulani/Feul, $12.9 \%$, Voltaiques $12 \%$, Songhai $6 \%$, Tuareg 5\%, Moors $5 \%$ and others $5 \%$. About $43 \%$ of the population live in urban centres and about $95 \%$ of the population are Muslims (Collins \& Burns, 2007; Dione \& Togola, 2018; Arieff , 2019). Of these ethnic groups, in Mali, Tuaregs and Moors are not part of the sub-Saharan aborigines. Tuaregs are a Berber ethnic minority group found in the Sahel and they are seen in Morocco, Niger Republic, Chad, Algeria, Libya, Burkina Faso and Tunisia. Haysom (2014) has observed that, despite the Tuareg geographical spread in the Sahelian countries, they are not a majority in any of these countries as its population in Mali and Niger is estimated at 800,000, which is the highest. Indeed, 
Mali has the highest Tuareg population of about 33\% of all Tuaregs in the Sahel and about $5 \%$ of the Malian population as stated earlier on. More so, the Tuareg is not the dominant group in Northern Mali where they declared an 'Azawad'. They are found in three northern cities of Gao, Kidal and Timbuktu with a sparsely population of about 2 million (D’Errico, Grazioli \& Mellin, 2017; Haysom, 2014).

Mali has a dominant Muslim population. About $90 \%$ of Malians are Sunni Muslims, $1 \%$ practice Christianity and the remaining $9 \%$ are adherents of traditional religion (Lebovich, 2019). The post- independence era witnessed the rise of Wahabbist and Salafist Islam in Mali, sponsored by non-governmental organizations (NGOs) in the Middle East and Asia. According to Dione and Togola (2018, p. 6), Saudi Arabia sponsored Afro Arabian Cultural Institute and Mountada, Libya sponsored the World Association for Islamic Call, Kuwait sponsored the African Muslims Agency, the United Kingdom bankrolled Islamic Relief and the United Arab Emirate funded the Hamdallaye Islamic Cultural Centre. Most of these Islamic charity NGOs built Islamic schools in Northern Mali and promoted Arabic language over the French and Bambara languages which are regarded as tokens of colonialism. These Quranic schools or Madrasas provided basic education for children in the region where colonial education is ineffective and poorly funded. At the dawn of the new millennium, there were about 520 Quranic schools in Mali with 13\% of Malian pupils and about 100,000 students, and by 2015, $17 \%$ of Malians were said to be Francophone (Gakou as cited in Dione \& Togola, 2018, p. 6). Growing by leaps and bounds, the Malian State acknowledged the ascendency of Islamic fervor in the State and President Alpha Konare created the High Islamic Council of Mali (HCIM) in 2000 which encompassed about 150 Islamic Associations. However, the state maintained its preference for secularism and allowed Islamic advocacy as part of the large vibrant civil society organizations in the country. This might as well have accounted for the controversial appointment of Dr. Mamadou Diamute'ne, the Secretary-General of HCIM as the Chairman of the Electoral Commission in 2001 (Thurston, 2013a). With the nullification of Algerian elections in late 1980s, believed to have been won by the Islamic Salvation Front (ISF), and subsequent suppression of this party by the Algerian State, the Salafist Group for Preaching and Combat (GSPC) migrated into Northern Mali and undertook several charity activities which endeared it to the population and eventually increased anti-government / Western sentiment in the region. It later transformed itself into the Al Queeda in Islamic Maghreb (AQIM) and shared condominium with the Movement for Unity and Jihad in West Africa (MUJWA) and Ansar al Din as the main jihadist elements promoting terrorism in Mali and across West Africa (Lacher, 2013; Arieff, 2019; Arieff \& Johnson, 2012).

Mali practices political secularism, having adopted the French doctrine of 'Laicite' at independence. In other words, there is a clear separation between the State and religion in Mali right from the days of colonial rule, through its independence in September 1960 
and till date (Wing, 2013; Dione \& Togola, 2018). The French handed over the power to a democratically elected government of Modibo Keita who ruled the country for about eight years and was overthrown in a military coup by General Moussa Traore. The coup followed the pattern of military involvement in politics in Africa as experienced in Togo, Benin, Nigeria and Ghana, amongst others, in the first decade of independence (Okeke \& Chukwuka, 2013; Nordlinger, 1976). The military junta adopted the one-party system and the Democratic Union of the Malian People (UDPM) dominated Malian political space for over two decades. General Traore was ousted by another military coup led by Lieutenant-Colonel Amadou Toumani Toure, in 1991. The new junta had no interest in transforming himself into a civilian ruler and organized a multi-party election in 1992 which was won by Alpha Oumar Konare who led a coalition of political parties, the Alliance Pour La Démocratie au Mali (ADEMA). The coalition won the 1997 general elections with Konare as the President, who eventually stepped down at the expiration of his tenure in 2002 (Reitano \& Shaw, 2015; Wing, 2013). Given the track record of Amadou Toumani Toure in terms of voluntary handling over the power to a civilian government, the Malian people entrusted the leadership of the state to him in the 2002 elections and he was reelected in 2007. However, he was deposed in a military coup in 2012 by Amadou Sanogo who ruled the Malian State for 21 days before he handed over the power to Diacounda Traore as the acting President. Traore organized elections in 2013 and handed over power to Ibrahim Boubacar Keita (IBK). President Keita was forced to resign from office on August 19, 2020 by military adventurists led by Colonel Assimi Goita, who negotiated with ECOWAS and other stakeholders for 37 days and eventually stepped down for Bah Ndaw on September 25, 2020. President Ndaw was the transition President of the country until he was overthrown in another military coup by Colonel Goita on May 24, 2021 (ECOWAS, 2020c; ECOWAS, 2020d; ECOWAS, 2021b).

Mali is a third world country by all indices and among the poorest in the world. According to Bastagli and Toulmin (2013), Mali is marred by poor infrastructure and about $80 \%$ of its population live in rural areas with widespread poverty. As a typical third world nation, the economy of Mali depends on the export of primary commodities, such as agriculture and mining. Mainguy (2010) observed that the Malian State received royalties and corporate taxes from foreign investors in gold mines and gold accounts for about three-quarters of the country's total export in recent years. The sector also provides employment for $15 \%(13,000)$ of the workforce in the formal sector of the economy (Drakenberg, 2010, p. 3). Of all agricultural export, cotton stands out as the prime commodity, accounting for $1 \%$ of the country's GDP and is second to gold. The country also grows grains for local consumption. However, unstable prices in the world commodity market and incessant drought threatened both the incentive to expand and the capacity to consistently increase production. Therefore, artisanal mining of gold becomes the safety net for farmers in the country, especially the women, in lieu of crop failure (Drakenberg, 2010; Bastagli \& Toulmin, 2013). 
Another feature of the Malian economy is the localization of productive activities (mining and agriculture) in the South and Western parts of the country. The lopsidedness of economic activities also replicated in the spread of the population across the country. Thus, the scarcity of economic activities and employment in the North creates discontentment in the midst of poverty and perceived marginalization (Dione \& Togola, 2018; Thurson, 2013a). With an average of USD230 annual per capital income, Malians are among the poorest in the world (Chene, 2008). This reality, amongst others, make Mali a major destination for foreign aid. For instance, in 2018, the US gave USD140 million as bilateral aid to Mali in support of development, health, governance, conflict mitigation and military training. The US also supported humanitarian service with USD82 million and the African Union peace support operations with USD317 million (Arieff, 2019, p. 2). Despite the high rate of poverty in this country, institutional corruption and elite involvement in corrupt practices further concretized the economic woes of the country (Bleck et al., 2016; Chene, 2008).

The paucity of the State presence in the North of Mali, as reflected in poor infrastructural facilities, education and economic opportunities, created a huge vacuum in the area. This gap was incrementally filled by Islamic non-governmental organization from Algeria, Saudi Arabia and other parts of the Middle East. These Islamic institutions built Islamic schools and provided social security to indigent citizens. Consequently, the people of Northern Mali owe greater allegiance to Islamic institutions which provide those needs neglected by the State. Such a shift of loyalty and the accordance of legitimacy to these religious bodies increased the de-legitimization of the central government of Mali in the North and promote rebellious culture against the Malian state (Bleck et al., 2016, Thurston, 2013a, Haysom, 2014). Scholars have also identified the thriving of smuggling and other criminal economy in the North with its neighbor. This region became the transition route for illicit drugs, human trafficking and kidnapping with the involvement of some influential elements in government. The high profile Air Cocaine's scandal was illustrative for the government involvement in rogue economy in the region. With the ascendancy of these economic activities and Islamic fundamentalism, which led to the kidnapping of 32 European tourists by GSPC in 2003, the thriving tourism industry in the region collapsed, and worsened the unemployment index, thus further entrenching poverty (Chauzal \& Van Damme, 2015; Reitano \& Shaw, 2015).

Mali has become a source of global and regional threat in the past decade due to the precarious socio-economic and security realities in the North. The convergence of Islamic fundamentalists, the revisitation of socio-political and economic marginalization by Tuaregs and emergence of criminal economics have made it difficult for the ill-equipped Malian Armed Forces to contain the violent outburst (Bleck \& Michelitch, 2015, Lebovich, 2019). History have shown that Mali has been a theatre of violence with four Tuareg rebellions and five military coups. The most outstanding was the 2012 Islamic uprising and insurgency which almost led to the Islamization of the country and 
its near break-up. The short-term management of the conflict has not led to a long-term resolution of the conflict. Thus, the Malian conflict of 2012-2021 is a relapse of the protracted conflict rooted in the historical foundation of the State, its structure, norms and processes. Its resolution, therefore, should not be restricted to transition to civil rule and some rhetorical commitment to implement peace agreement(s) as done in the past.

\section{Theoretical Framework}

The preferred framework for this study is the Power Theory. Proponents of this theory include Arnold Wolfers (1962), Hans Morgenthau (1967) and Joseph Frankel (1973). Wolfers (1962) refers to power as the ability to make people to do what one desires, not to do what one does not approve, since it involves the ability to move others by the threat or affliction of deprivation. In other words, it is the capacity to get one's wishes carried out despite opposition, and the capacity to influence the actions of others in accordance with one's own ends (Frankel, 1973). This is simplified by Dahl's (1969, p. 80) explanation that ' $A$ has power over $B$ to the extent that he can get $B$ to do something that $B$ would not otherwise do'. According to Morgenthau (1967), political power is derived from and measured by both tangible and intangible assets of a nation or region. Tangible assets (hard power) include military capability and technology, level of industrialization, resource endowment, level of economic and political development, population and geostrategic location, while intangible assets (soft power) include culture, values and foreign policy (Nye, 2004). The optimum combination of both types of power in the management or resolving violent conflict is seen as the deployment of 'smart power' of an actor (Wilson, 2008). The basic axiom of Power Theory is the imposition of ones will on other(s). The relevance of the theory to this study lies on its explanation of the gaps in ECOWAS responses to the Malian conflict 2012-2021, which may be attributed to its power deficits and inability to enforce its will on other actors in the conflicts.

\section{Methodology}

The case-study design is adopted because it probes deeply, intensively, and analyzes the interaction between factors involved in the study (Idaka \&Anagpogu, 2012). This has the advantage of identifying the major issues in the Malian conflicts as well as outlining ECOWAS responses and the gaps in them. It also has the advantage of providing a yardstick for similar studies on conflicts in other regions of the world. This study focuses on ECOWAS response in the Malian conflict but also covers issues of common concern to all regional groupings saddled with the responsibility of intervening in violent conflicts in their domain. It relies on secondary data from extant literature such as textbooks, magazines, communiqué, scholarly journals and the internet. This data was presented qualitatively and content analysis technique was used in the analysis of the research findings.

The Analysis of Malian conflict (2012-2021) is presented on the table below: 
The Analysis of the Malian 2012-2021 Conflict

\section{Profile of the conflict}

The conflict centers on the structure and processes of the Malian State, as presently constituted, the state and nation building, as well as the consolidation of democracy and its ethos in a security challenged environment.

\section{Actors in the Conflict}

There are multiple actors in the conflict and could be classified into two classes: the endogenous and exogenous actors. Actors within Mali include (1) the central government, which failed to integrate the Northern part of the country with the rest of the Malian State, (2) separatist Tuareg rebels who violently campaigned for the independence of the 'Azawad', (3) the terrorist groups (AQIM, MUJAO) who fought for the establishment of an Islamic state in Mali, (4) criminal entrepreneurs who crisscrossed the country's borders with illicit arms, drugs, human trafficking and kidnaping for ransom, (5) Islamic NGOs with radicalization agenda, and (6) the Malian Armed Forces which struggled to secure the country and also plot the coups. The external actors consist of the tricentric level of analysis - Malian neighbors, ECOWAS and the AU, and extra-continental elements. Algeria has been a perpetual mediator between the Malian state and Tuaregs. She tacitly pushed out her radicalized Islamic elements and AQIM to live in northern Mali. Niger, just like Algeria, worked against the Tuaregs' Azawad dream since it may trigger similar demands from the Tuaregs in her territory and elsewhere in the region. Besides, Malian neighbors tacitly approved the criminal economy in Northern Mali as illicit commodities passed through their borders with little or no restraint. ECOWAS, on the other hand, is involved in diplomatic maneuvering with successive military juntas since 2012 for the return to civil rule, as well as mobilization of troops for PSOs in the conflict zone.

The African Union (AU) also participated in diplomatic solutions and PSO through the Africanled International Support Mission to Mali (AFISMA). Outside Africa, France acted as the first responder when her airplanes were sent to halt the jihadist advancement to central and southern Mali. France also has 5,100 troops in Mali and works with other members of the UN Security Council to approve the deployment of PSOs. This was understood against her status as the former colonial master of Mali with vested interest in every development in the country and region. The US deployed its military asset to Mali as part of her counter terrorism operations in the Sahel region and continues to provide military /counterterrorism aid to Mali. The United Nations established a 3,000-man United Nations Multidimensional Integrated Stabilization Mission in Mali (MINUSAMA) and it is ongoing. It has the objective of stabilizing the security barometer in the country. On the other hand, member states were complacent about the socio-economic and political marginalization in the country.

\section{Causes of the conflict}

The central cause of the conflict is the faulty structure of the Malian State. This is aggravated by political and economic marginalization as well as social stigmatization of the Tuaregs and vices. The geo-strategic location of Mali in the Sahel exposes it to radical Islamic adventurists. Climate change induced drought leads to farmers/herders conflict and global revival of Islamic Wahhabism and Salafism in the country. Weak armed forces with political ambition accounts for recent coups. The collapse of Muamar Gaddafi and proliferation of small arms and light weapons in the region provide the means for the escalation of the conflicts since 2012. 


\section{Dynamics of the conflict}

The 2012-2021 conflict in Mali has a remarkable implication on both the regional security of West African states and the global security. The continuous weakening of the cohesion between the ruling elite and the military may provide opportunity for the Jihadists to make attempts to overrun the country again, as done in 2013. A radical Islamic enclave, as envisaged by AQIM and ISWAP in northern Mali, could become a safe haven for terrorists, as experienced in Afghanistan before the 9/11 attack. Besides, such an enclave could become a launching pad for attacks on Western targets within and outside Africa. The best-case scenario is for all stakeholders to make Mali a vibrant state free of Islamic terrorists' occupation of any of its territory, as well as get Bamako to prioritize politico-economic and social inclusion of the Tuaregs and other northern minorities in the mainstream of national activities.

Worse still, the junta's Colonel Assimi Goita may hold on to power at his second coming from May 24, 2021, and orchestrate a transition to civil rule which transmutes him to a civilian President. Such decision could attract the anger of civil society organizations in Mali and lead to massive protests as done against the former President Ibrahim Keita in June 2020. Besides, regional and global economic embargoes, as responses to such decision, would further weaken the fragile economy of the Malian state, and the required military support of the West for its counterterrorism operations and security sector reforms in the country.

However, a national dialogue on the future of Mali is very important. The Malian state is a product of French patrimony and the insistence on the sacrosanctity of the colonial boundary is a major source of conflict in Africa and Mali. A creation of an Azawad for all the Tuaregs in the Sahel could be very dignifying, even when the viability of such state is questionable. In all, there must be a deliberate effort at state building in Northern Mali and containment of corruption by Malian elites, if the present conflict is to be transformed to an instrument of national rebirth.

Source: Compiled by the author

\section{ECOWAS response to the Malian conflict 2012-2021}

The enabling framework for ECOWAS's response to the Malian conflict include, amongst others, the protocol on the Mechanism for Conflict Prevention (1999) and the Supplementary Protocol on Democracy and Good Governance (2001). These protocols are mutually reinforcing instruments of the ECOWAS Conflict Preventive Framework (ECPF) (Atuobi, 2010; Okon \& Williams, 2018). Mali is a signatory to the framework which despise the unconstitutional change of the government in the member states and emphasizes the sanctity of the ballot box and the completion of executive tenure in office as spelt out by the countries' constitution. Hence, the military coup of March 22, 2012, led by Captain Amadou Sanogo, marked the entrance of ECOWAS to the Malian conflict (Alozieuwa, 2013; Francis, 2013).

The regional body condemned the coup and, in collaboration with the African Union (AU), suspended Mali from its fold. ECOWAS also lobbied the UNSC to condemn the putsch and call for the immediate release of detained President Amadou Toumani Toure 
and others arrested during the coup. ECOWAS also initiated diplomatic missions to Mali to persuade the military junta to restore the overthrown government. The then President of ECOWAS, Alassane Ouattara, had an abortive trip to Bamako on March 22 and the subsequent meeting of the regional body held in Abidjan gave the Malian junta 72 hours to handover to the embattled administration. At the expiration of the ultimatum, ECOWAS unveiled a series of sanctions against the junta, and these included the freezing of the Malian state accounts in West African Central Bank, travel bans and freezing of the junta's assets, and denial of port access and border closures. The impact of the sanction was immediate, as Sanogo and his cohorts agreed to discuss with ECOWAS. Although the previous constitutional order was not restored, the junta agreed with the formation of a transition government headed by a civilian - the President of the Parliament, Dioncounda Traore, and the resignation of President Amadou Toumani Toure on April 20, 2012. ECOWAS also upturned the 40 days election timetable sanctioned by the junta and extended the lifespan of the transition government to 12 months. Everyone arrested during the coup was released from detention (Alozieuwa, 2013; Francis, 2013).

Haysom (2014) noted that, with French support, ECOWAS proposed a political and military intervention with its mobilization of the 3000 strong ECOWAS Standby Force (ESF) for the ECOWAS Mission in Mali (MICEMA), and then the AFISMA, which were blocked by both Algeria and Mauritania. Besides, the UN was skeptical about the ECOWAS' capacity to resolve the conflict, since the sub-regional body regarded the junta as an illegitimate regime. More so, the organization was perceived to lack the capacity to undertake such a mission and there was a fear of strategic danger of dispersing terrorist fighters in Northern Mali, if the mission was poorly executed.

A similar sentiment was expressed in August 2012 by Arieff (2012) as he observed that ECOWAS sanction 'underscored its operational shortcomings, but warned that a delay in confronting armed groups in the north, including terrorist actors could enable them to consolidate or expand their hold, it could also lead to open conflict among various entities vying for control' (p. 2). This was prophetic as the delay by global actors to support ECOWAS with the needed financial and logistic supports did not only lead to belligerents' battle for supremacy and control; the victorious jihadist in the northern power contest unfolded their caliphate agenda and expanded towards Bamako. Nevertheless, ECOWAS formed the bulk of AFISMA contingent which complemented the French airstrike that halted and killed the caliphate ambition of the Jihadists (Haysom, 2014; D'Errico et al., 2017). ECOWAS troops also remained in the UN Multidimensional Integrated Stabilization Mission in Mali (MINUSMA) since 2013. This had encouraged the deployment of the European Union training mission in 2013, the French-led operation Barkhane and the G5 Sahel joint task force in 2014 respectively. These PSOs are ongoing and were instrumental to the relative stability which facilitated the peace talk 
between the government and the belligerents, as well as the conduct of presidential and legislative elections in late 2013. The emergence of Ibrahim Boubacar Keita as President in the 2013 elections was greeted with optimism and so was the Algeria mediated peace agreement signed in 2015 (Lamarche, 2019; Arieff, 2019). However, scholars attributed the ongoing crisis to the stalled implementation of the 2015 peace agreement and the endemic corruption of Keita's government which alienated the majority of the governed from the state and promoted socio-economic discontentment and widespread poverty in the pandemic environment (Arieff, 2019; Bleck et al., 2016; Lemarche, 2019).

Through data obtained and analyzed by the ECOWAS early warning system, it was obvious that another political conflict was brewing in Mali in 2020, a reminiscence of the 2012 scenario. Consequently, ECOWAS heads of state and government held an extraordinary summit through video-conference on July 27, 2020 to evaluate the situation characterized by a serious security threat with recurring terrorist attacks and inter-community tensions in the central part of the country. Besides, there was also social tension arising from demonstration by June $5^{\text {th }}$ Movement - Group of Patriotic Force (M5-REP), a group comprising political parties, civil society and religious organizations, all together with a prolonged strike by school teachers in the midst of the COVID-19 pandemic and its attendant financial and economic challenges (ECOWAS, 2020a). The summit was a follow-up to the earlier ECOWAS ministerial mission sent to Bamako between 18 and 20 June, 2020, to determine the causes of the conflict and propose solutions through recommendations. Those recommendations were not implemented and that contributed to the deterioration of a violent demonstration with high casualties between July 10 and 12 and destruction of private and public property. Consequent to the violent outburst, ECOWAS appointed Dr. Goodluck Jonathan, the former Nigerian President, as a mediator in the conflict and he visited Bamako between 15 and 19 July with his team. The mediation team met with stakeholders and drew a road map for peaceful resolution of the conflict, but the M5-RFP was adamant on its demands on the resignation of President Ibrahim Keita, the formation of a transitional government, the establishment of a commission of inquiry to investigate the death of protesters in July 10-12 demonstration, and the release of Soumaila Cisse, the opposition leader abducted at the eve of the parliamentary election in March. The M5-RFP also threatened to continue with street protests until their demands were met (ECOWAS, 2020a). Based on the outcome of the mediation, ECOWAS sent a fact-finding mission of (5) Heads of State - Mahamadou Issoufou of Niger and Chair of the ECOWAS authority, Nana Akufo Addo of Ghana, Alassane Ouattara of Cote d'Ivoire, Muhammadu Buhari of Nigeria and Macky Sall of Senegal - to Mali on July 23, 2020. The mission met with all parties in the conflict and insisted on the supremacy of the country's institutions, especially the sacrosanctity of ballot box as the only means of ascending to power in line with the ECOWAS Protocol on Democracy and Good Governance (Atuobi, 2010; 
Okon \& Williams). In addition, the mission decided as follows:

(a) that political parties ensure the resignation of 31 members of Parliament whose elections were contested,

(b) immediate recomposition of the Constitutional Court,

(c) the establishment of a Government of National Unity led by Prime Minister Boubou Cisse, with 50\%, 30\% and 20\% from members of the ruling coalition, opposition parties and civil society, respectively,

(d) investigation of the causes of July-10-12 violent demonstration, identification of perpetrators for prosecution and compensation for the wounded and family of the dead and the setting up of monitoring committee made up of the conflicting parties to oversee the implementation of these decisions within 10 days (ECOWAS, 2020a).

The ECOWAS mediator was in Mali in the second week of August to review the implementation of the decisions reached during the video-conference Extraordinary Summit of July 27,2020. The mission observed that progress was made in the recomposition of the Constitutional Court, amongst others. But on August 18, Colonel Assimi Goita announced a military takeover of the country's leadership and arrested President Ibrahim Keita and other top government functionaries. Some days later, the embattled President was forced to resign and announced the dissolution of the National Assembly. Following the development, ECOWAS condemned the coup and called for continental and global rejection of the putsch. It also invoked all the sanctions, as was done in 2012 - the freezing of Malian state account with the Central Bank of West African State, travel ban on the junta, as well as denial of port access and border closure. ECOWAS also put the ESF on a standby for possible deployment to Mali and suspended Mali from all ECOWAS decision-making bodies with immediate effect (ECOWAS, 2020b). These measures were transmitted to the AU, EU, the UN and their support was total. Following a series of consultation and negotiation with the junta, the former Defense Minister - Bah Ndaw was nominated and sworn in as the interim President. He was saddled with the responsibility of organizing presidential and legislative elections in eighteen months. The head of the military junta, Colonel Assimi Goita, was appointed Vice-President of the interim government with the responsibility of overseeing the security and defense of the country.

Consequently, an ECOWAS mediation team visited Bamako between September 23-25, 2020 , to assess the implementation of earlier decisions made on the resolution of the conflict such as the restoration of constitutional order in Mali and the release of those detained by the junta. The mediation team held discussions with President Bah Ndaw, Colonel Assimi Goita, ECOWAS member states' ambassadors accredited to Mali as well as the ambassadors of the Big Five members of the UNSC and EU in Mali. The mediation team insisted on the release of all members of former administration still under detention and the urgent need to appoint a civilian Prime Minister to oversee 
the drafting and implementation of political transition and various reforms of an inclusive national dialogue.

More so, the Goodluck Jonathan-led mediation mission called for a clean-up of the transition charter which would reflect the decision of the ECOWAS leadership on the dissolution of the junta's National Committee for the Salvation of the People (NCSP) before / after the swearing in of the interim President, the clarification of the responsibilities of the Vice President in charge of security and defense, the impossibility of the Vice-President to replace the President, and the sanctity of the eighteen months transition period with effect from September 15, 2020 (ECOWAS. 2020c). The report of the mediation mission outlined the membership of the monitoring committee as was named by the ECOWAS leadership to work in conjunction with bilateral and multilateral partners to support the transition process (ECOWAS, 2020d). With the appointment of Moctar Ouane as the interim/transitional Prime Minister, the chair of the ECOWAS Authority of Heads of State and Government, Nana Akufo-Addo, visited Mali to assess the progress made in the transition process and affirm the support of the regional body to the process. He was accompanied by the ECOWAS mediator, Dr. Goodluck Jonathan, amongst others. He had discussions with three major players in the transition process — President Bah Ndaw, Colonel Assimi Goita and Prime Minister Moctar Ouane. He praised the Malian authority for the progress made in line with the ECOWAS decisions, considering the release of all those detained by the junta, the appointment of President and Prime Minister, as well as the ratification of the Transition Charter and urged the transition authorities to design the calendar of the electoral process in accordance with the 18 months deadline agreed upon (ECOWAS, 2020d). Another visit by the ECOWAS mediation team to Mali took place on January 12, 2021 and was led by Dr. Goodluck Jonathan, the Chief Mediator. The objective of the visit was to evaluate the progress made towards effective transition. The mission met with major stakeholders and the heads of transitional institutions as done by Chair of ECOWAS Authority of Heads of State and Government. At the end of the meeting, the mission noted with concern the complaints of poor consultation made by some stakeholders in spite of the progress made. It also called for the scrapping of the junta's CNSP since key transitional institutions were in place. It insisted on the primacy of adequate consultation with all key stakeholders in the transition program to enhance their buy in and ownership since such process is essential for transparent, free and fair elections, and indeed the entire transition to civil rule program (ECOWAS, 2021a).

In all, Mali, with the support of ECOWAS, was making progress towards a successful transition to civil rule until the sacking of the transitional government by Colonel Assimi Goita on May 24, 2021. Goita was the Vice President and the leader of the junta in the August 18, 2020 putsch. ECOWAS response was to condemn the coup in the strongest term as usual and imposed its traditional sanctions as were done in 2012 and 
August 2020 (ECOWAS, 2021b). It is, therefore, important to evaluate the inadequacy of ECOWAS mediation in Mali which explains the cyclical pattern of instability in the country.

\section{The Gaps in the ECOWAS mediation of the conflict}

The ECOWAS dominance in finding solution[s] to the on-going conflict in Mali is salutary, but there are questions on Algeria and other neighboring spoilers and how to checkmate their activities. Algeria has been a perpetual mediator between the Malian state and Tuareg rebels over time due to its affinity with Tuaregs and its utilization of the ungoverned space in Northern Mali as home for its Islamic terrorists and dissidents. ECOWAS' inability to influence Algeria and similar interests in the resolution of the conflict remains a gap since Northern Mali has become a safe haven for Foreign Terrorist Fighters (FTF) who were forced out of Algeria, and many of them desire the maintenance of the chaotic status quo for the safety, security and prosperity of their criminal economy (Lacher, 2013; Reitano \& Shaw, 2015). The continuous exclusion of ECOWAS in the peace negotiation process with Tuaregs and other belligerents in Northern Mali has reduced the status of the sub-regional body as an important stakeholder in the peace and security of the country, hence, the belligerents hardly see ECOWAS as a partner for sustainable peace and prosperity of their domain. Similarly, the continuous patronage of Algeria in the negotiation with the Tuaregs and aggrieved elements in the region is counter-productive since those agreements incrementally serve to appease the belligerents and Algerian interest. In other words, those agreements are meant to strengthen the belligerents and give Algeria condominium over Malian territory, a situation which could be seen as one state with two governments (Chauzal \& van Damme, 2015; Caparini, 2015). Given this reality, the best effort of ECOWAS at making peace in Mali tends to yield a minimal result in a very unfriendly neighborhood. In sum, Algeria's involvement and its interest in keeping its radical elements at the Malian border and the inability of ECOWAS to check this trend remains a gap, since this variable has the potential to stall the implementation of agreements and ignite conflict in future as experienced since 1963 till date (Dione \& Togola, 2018; Lacher, 2013).

Another gap in the ECOWAS response to Malian conflict since 2012 is the poor monitoring and probing of Ibrahim Boubacar Keita's government. ECOWAS leadership is quick to invoke its provision on zero tolerance for unconstitutional change of government against entities who decide to change bad and corrupt leadership, but nothing is done to check the excesses of those in power. Instances of corruption and complacency in criminal activities leveled against the Malian government includes the viral Air Cocaine scandal, yet ECOWAS did nothing to verify these corrupt practices despite sub-regional instruments against these vices (Bleck \& Michelitch, 2015; Hagan \& Harvey, 2016). By rejecting the good governance, characterized by respect for the rule of law; transparency 
and accountability in governance, freedom of the Press, predictability in government behavior, expectation of rational decisions by government; people-oriented policies and openness in government transactions, the Malian leadership was courting another crisis, which ECOWAS ought to have noted and discussed with Toure and Keita (Eneanya, 2009, pp. 220-221). In addition, ECOWAS' tolerance of bad governance from its members reduces its integrity and legitimacy among actors and entities in the sub-region. This justifies why attempts by the ECOWAS leadership to mediate in some crises in the region are rebuffed and seen as means of supporting one of their own and ensure personal and regime security of a bad leader (Alozieuwa, 2013; Ofuatey-Kodjoe, 1994). The African Peer Review Mechanism (APRM) is handy and many West African states are signatories which makes it easy to be regionalized and make periodic peer review mandatory instead of voluntary (Grudz, 2009). It is indeed the failure of ECOWAS to ensure the implementation of Algeria agreements, monitor the distribution of public goods, especially those from donor agencies to the impoverished North, as well as the ascendancy of parochial interests of elites over that of the nation that continues to generate ripples that threaten the state stability. ECOWAS, therefore, needs to close the gap between shoot and vote models and address the root causes of the Malian conflict which it failed to do in the last ten years (Chauzal \& Van Damme, 2015; Wing, 2013).

Going forward, the French interest in its former colonies generates yet another gap in the ECOWAS' response to Mali conflict between 2012 and 2021. For instance, ECOWAS PSO metamorphosed from MICEMA to AFISMA due to French influence on the preferred first responder to the conflict (Lamarche, 2019). Therefore, ECOWAS is cautious in deciding every step in its response to Malian conflict since the French has the capacity to veto such decisions and actions at the UNSC (Akinboye \& Attoh 2005). Such scenarios hardly play out in the Anglophone countries in the region, where ECOWAS unilaterally initiated PSOs in Liberia (1990), Sierra Leone (1997), Guinea Bissau (1999) and, recently, Gambia (2016). ECOWAS' capacity to predict French policy options at every stage of the conflict remains a gap that must be filled to initiate and undertake timeous measures to enhance stability and peace building in Mali. For instance, ECOWAS did not want to discuss with Captain Sanogo in 2012 after he took power from Toure. However, the restoration of the constitutional order under Toure was a closed chapter as France called for an early election, instead of restoring the preceding order (Guindo, 2018). Given this reality, ECOWAS had to follow the same direction. Similarly with the acceptance of the coup against Keita by France, ECOWAS had to reiterate to Malians and global community that its mission in the Sahel country was mainly concerned with the preservation of constitutional democracy, but not with the provision of support to any regime (ECOWAS, 2020c).

ECOWAS response to the Malian conflict has also revealed a huge gap between its aspiration and capacity. Since the end of the Cold War and the emergence of 'new wars' 
in Africa, ECOWAS has positioned itself as the 'gateway' for the EU and other partners in attracting resources for capacity building of its PSO institutions (Ellowson \& MacDermott, 2010). In spite of these efforts, the gap between ECOWAS ambition to be a security community with timeous response to multidimensional security threats in West Africa is enormous. This is due to the weakness of key institutions in the sub-region as well as poor funding and lack of equipment / logistics and infrastructural facilities. More so, most of the countries in the sub-region do not have well trained personnel in security related institutions for immediate deployment to conflict zones. This is complicated by the menace of terrorism and insurgency in the sub-region which has affected the capacity of Nigeria to play its traditional role of a sub-regional hegemon in conflict management in the region (Ellowson \& McDermott 2010; Onuoha, 2014). Specific to Mali is the challenging terrain of the Sahel which presents operational difficulties to even the best security operators in the world. Besides, the massive landmass of Northern Mali is a challenge to effective security coverage in terms of manpower and equipment required for such operation. ECOWAS, as highlighted earlier, does not have such capacity and therefore relies on partners for all round supports, which sometimes do not come on time (Tepjar \& Albuquerque, 2015). On the other hand, the sub-regional body enjoys great skills in responding to conflict in micro-states such as Liberia, Sierra Leone and Gambia where the land mass is relatively smaller and the operational requirements are easily met by Nigeria and other partners in a coalition of the willing.

\section{Conclusion}

Mali has suffered political convulsion inherent in post-colonial and fragile state due to the contradictions and manipulations entrenched in its foundation. The politico-economic marginalization and social stigmatization of the Tuaregs are the root causes of the conflict since independence. This is exacerbated by drought, the revival of Islamic fundamentalism, proliferation of SALW arising from the fall of Gaddafi, poor state penetration of Northern Mali and governmental corruption, as well as its massive landmass. The failure of the Malian state to address fundamental issues since the first Tuareg rebellion continues to explode with violent outburst as illustrated by numerous coups and rebellions. The outburst of 2012 has refused to calm and continues to threaten the very existence of the state till date. ECOWAS formed as an economic integration instrument in 1975 has transmuted to a conflict management / resolution entity since the end of the Cold War. Its intervention or response to the Malian conflict since 2012 and its gaps were the subject of this study. The study shows that while ECOWAS has the enabling framework to respond to the current conflict, it is hindered by the overbearing interest of Algeria and other neighbors, as well as France. Additionally, ECOWAS' inability to address governance deficits in Malian politics, especially the marginalization of the minority Tuaregs and governmental corruption weaken its legitimacy as an impartial arbiter. More so, the sub-regional body lacks the capacity to undertake massive response 
required in the difficult terrain with massive landmass. ECOWAS needs to participate in negotiations for lasting peace in Mali and initiate road map for the implementation of the peace agreement. In addition, ECOWAS needs to domesticate and mandate member states to incorporate the African Peer Review Mechanism into their domestic policy and work for compulsory biennial review of member States in order to reduce governmental deficits that generate tension in Mali and elsewhere in the sub-region.

\section{References}

1. Akinboye, S., \& Attoh, F. (2005). Systematic approach to international relations. Concept Publication.

2. Alozieuwa, S. (2013). The March 22, 2012 coup in Mali. Democracy and Security, 9(4), 383-397.

3. Arieff, A., \& Johnson, K. (2012). Crisis in Mali. Congressional Research Service.

4. Arieff, A. (2019). Conflict in Mali. Congressional Research Service.

5. Atuobi, S. (2010). Implementing the ECOWAS conflict prevention framework. Prospects and challenges. Kofi Anan International Peacekeeping Training Centre.

6. Bastagli, F., \& Toulmin, C. (2013). Mali: Economic factors behind the crisis. European Parliament.

7. Bleck, J., \& Michelitch, K. (2012). The 2012 crisis in Mali: Ongoing empirical state failure, African Affairs, 114(457), 598-623.

8. Bleck, J., Dembele, A., \& Guindo, S. (2016). Malian crisis and the linger problem of good governance. Stability International Journal of Security \& Development, 5(1), 1-18.

9. Caparini, M. (2015). The Mali crisis and the responses by regional actors. Norwegian Institute of International Affairs.

10. Chauzal, G., \& Van Damme, T. (2015). The roots of Mali's conflict. Moving beyond the 2012 crisis. Clingendael Institute.

11. Chene, M. (2008). Overview of corruption and government's efforts against corruption in Mali. Transparency International.

12. Collins, O., \& Burns, J. (2007). A history of sub-Saharan Africa. Cambridge University Press.

13. D'Errico, M., Grazioli, F., \& Mellin, A. (2017). The 2012 crisis in Mali and its implications on resilience and food security. FAO.

14. Dahl, R. (1969). The concept of power. In R. Bell, D. Edwards and H. Wagner, (Eds.), Political power: A reader in theory and research (pp. 79-93). The Free Press.

15. Dione, S., \& Togola, B. (2018). Historicizing ethno-religious and political conflicts in West Africa: The Mali case. Budapest International Research and Critics Institute Journal, 1(4), 1-15.

16. Drakenberg, O. (2010). Mining in Mali. A background note for the Swedish International Development Cooperation Agency. University of Gothenburg.

17. ECOWAS. (2020a, July 27). Declaration of ECOWAS Heads of State and Government on the socio-political crisis in Mali. ECOWAS. 
18. ECOWAS. (2020b, August 20). Statement by ECOWAS Heads of state and government on Mali. ECOWAS.

19. ECOWAS. (2020c, September 25). Communiqué: ECOWAS mediation mission in Mali. ECOWAS.

20. ECOWAS (2020d, October 11). Communiqué: Mission of the chair of the ECOWAS authority of Heads of State of Government to Mali. ECOWAS.

21. ECOWAS. (2021a, January 12). Communiqué of the ECOWAS evaluation mission on the ongoing transition in Mali. ECOWAS.

22. ECOWAS. (2021b, June 8-9). Communiqué of the ECOWAS mediators' mission to Mali. ECOWAS.

23. Ellowson, C., \& MacDermott, J. (2010). ECOWAS capabilities in peace and security: A scoping study of progress and challenge. Swedish Defense Research Agency.

24. Eneanya, A. (2009). Public administration in Nigeria: Principles, techniques and applications. Concept Publication.

25. Francis, D. (2013). The regional impact of the armed conflict and French intervention in Mali. Norwegian Peacebuilding Resource Centre.

26. Frankel, J. (1973). Contemporary international relations theory and behaviour of states. Oxford University Press.

27. Grudz, S. (2009). The African Peer-Review mechanism: Assessing origins, institutional relations and achievements. South African Institute of International Affairs.

28. Guindo, D. (2018). Why has ECOWAS not taken the lead role in addressing the Malian crisis. MA thesis presented at the Naval Post-Graduate School, Monterey, California.

29. Hagan, A., \& Harvey, I. (2016). The internal mechanism of cocaine: The evolution, risks, and sentencing of body packers. Forensic Research \& Criminology International Journal, 2(5), 191-203.

30. Hayer, K. (2013). Crisis in Mali: A peace building approach. International Alert.

31. Haysom, S. (2014). Security and humanitarian crisis in Mali: The role of regional organizations. Overseas Development Institute.

32. Idaka, I., \& Anagbogu, G. (2012). Research design. In A. Isangedighi (Ed.), Essentials of research and statistics in education and social science (pp. 65-79). Eti Nwa Associates.

33. Lacher, W. (2013). The Malian crisis and the challenge of regional security cooperation, Stability International Journal of Security and Development, 2(2), 1-5.

34. Lamarche, A. (2019). Mali's humanitarian crisis: Our militarized and overshadowed. Refugees International.

35. Lebovich, A. (2019). Sacred struggles: How Islam shapes politics in Mali. European Council on Foreign Relations.

36. Mainguy, C. (2010). Natural resources and development. The gold sector in Mali, Resources Policy, 36, 123-131.

37. Morgenthau, H. (1967). Politics among Nations. Knopf.

38. Nordlinger, E. (1976). Soldiers in politics: Military coups and governments. Prentice Hall.

39. Nye, J. (2004). Soft power: The means to succeed in world politics. Public Affairs. 
40. Ofuatey-Kodjoe, W. (1994). Regional organizations and the resolution of Internal conflict: The ECOWAS interventional in Liberia. International Peacekeeping, 1(3), 261302.

41. Okeke, V., \& Chukwuka, U. (2013). Nigerian political culture: The saga of militarism. Review of Public Administration and Management, 2(3), 84-97.

42. Okon, E., \& Williams, D. (2018). Burundi and Gambia: Regional security and rapid deployment capability. The utility of the African Standby Force. Conflict Studies Quarterly, 24, 44-70.

43. Oluwadare, A. (2014). The African Union and the conflict in Mali: Extra regional influence and the limitations of regional actor. Journal of International and Global Studies, 6(17), 106-120.

44. Onuoha, F. (2014). Danger not only to Nigeria alone - Boko Haram transnational reach and regional response. Fredrich Ebert Stiftung.

45. Reitano, T., \& Shaw, M. (2015). Fixing a fractured state. Breaking the circles of crime, conflict and corruption in Mali and Sahel. Global Initiative Against Transnational Organized Crime.

46. Tepjar, J., \& Albuquerque, A. (2015). Challenges to peace and security in West Africa: The role of ECOWAS. Swedish Defense Research Agency.

47. Thurston, A. (2013a). Towards an Islamic Republic of Mali?. The Fletcher Forum of World Affairs, 1(2), 45-66.

48. Thurston, A. (2013b). Mali: The disintegration of a model African democracy. Stability, 2(1), 1-7.

49. Wilson, E. (2008). Hard power, soft power, smart power. The Annals of the American Academy of Political and Social Sciences, 616(1), 110-124.

50. Wing, S. (2013). Mali's precarious democracy and the causes of conflict. Special Report 331. USIP.

51. Wolfers, A. (1962). Discord and collaboration. John Hopkins Press. 